\title{
NK cells protect TCR-transgenic mice from developing fetal leukemia
}

\author{
Sigrid Dubois ${ }^{1 *}$, Jürgen Müller ${ }^{1}$, Lionel Feigenbaum² ${ }^{2}$ Thomas A Waldmann ${ }^{1}$ \\ From Society for Immunotherapy of Cancer 29th Annual Meeting \\ National Harbor, MD, USA. 6-9 November 2014
}

To investigate the intrinsic effect of IL-15 expression on CD8 responses we generated IL-15-deficient OT1 TCRtransgenic mice. These mice died surprisingly at around six months of age exhibiting grossly enlarged lymph nodes, spleens and thymi. The affected organs harbored mainly CD8+ T cells that were low for MHC class I, expressed CD25 and CD24 as well as the co-stimulatory receptors $\mathrm{CD} 28$, ICOS and PD1. This phenotype resembled a sub-population of immature CD8 singlepositive thymocytes. These co-stimulatory receptor-positive CD8 cells (CD8cor) expanded after transfers into mice that lacked NK cells due to IL-15 inhibition or antibody-mediated cell lysis, and NK cells caused in vivo lysis of CD8cor cells. In contrast, the presence of IL-15dependent $\mathrm{CD} 8+\mathrm{T}$ cells had no effect on CD8cor cell expansion. In vivo expansions of CD8cor cells also depended on the presence of CD11c-positive dendritic cells while IL-2 activity was dispensable despite high CD25 expression. These data suggest that NK cells prevent the thymic escape of a sub-population of CD8 single-positive thymocytes and their subsequent malignant transformation in TCR-transgenic mice.

\section{Authors' details}

'Lymphoid Malignancies Branch/CCR/NCl, Bethesda, MD, USA. ${ }^{2}$ Transgenic

Mouse Model Laboratory, LASP, NCl, Frederick, MD, USA.

Published: 6 November 2014

doi:10.1186/2051-1426-2-S3-P167

Cite this article as: Dubois et al:: NK cells protect TCR-transgenic mice

from developing fetal leukemia. Journal for ImmunoTherapy of Cancer

2014 2(Suppl 3):P167.

${ }^{1}$ Lymphoid Malignancies Branch/CCR/NCl, Bethesda, MD, USA

Full list of author information is available at the end of the article

Submit your next manuscript to BioMed Central and take full advantage of:

- Convenient online submission

- Thorough peer review

- No space constraints or color figure charges

- Immediate publication on acceptance

- Inclusion in PubMed, CAS, Scopus and Google Scholar

- Research which is freely available for redistribution 